\title{
Pendukung Keputusan Dalam Peramalan Penjualan Ayam Broiler Dengan Metode Trend Moment Dan Simple Moving Average Pada CV. Merdeka Adi Perkasa
}

\author{
Win Kurniadi \\ Program Studi Komputerisasi Akuntansi, AMIK BSI Karawang, Indonesia
}

\begin{abstract}
Abstrak
Peramalan merupakan perkiraan tingkat permintaan satu atau lebih produk selama beberapa periode mendatang. Dalam meramalkan perkiraan tingkat permintaan guna tidak terjadi berlebihnya dan tidak kurang jumlah persediaan ayam broiler dengan berdasarkan penjualan di masa lalu. Pendukung keputusan yang diteliti untuk memprediksi jumlah permintaan dengan menggunakan metode trend moment dan metode simple moving average serta mengukur tingkat keakurasian meramal dengan metode mean absolute percentage error. Dengan kedua metode tersebut hasil penelitian menunjukkan bahwa metode trend moment memperoleh hasil mean absolute percentage error tertinggi $4.08 \%$ dan terendah $36.12 \%$ sedangkan metode simple moving average memperoleh hasil mean absolute percentage error tertinggi $3.25 \%$ dan terendahnya $23.12 \%$.
\end{abstract}

Kata Kunci: Pendukung Keputusan, Penjualan Ayam Broiler, Trend Moment

\section{Abstract}

Forecasting is the approximate level of demand for one or more products over the coming periods. In forecasting the level of demand for no excess and no less the amount of broiler chicken stock based on sales in the past. Decision supporters are investigated to predict the number of requests using trend moment method and simple moving average method and measure the level of accuracy predict by means of mean absolute percentage error. With both methods, the result of the research showed that trend moment method obtained the highest mean absolute percentage error of $4,08 \%$ and the lowest was $36.12 \%$ while the moving average method obtained the highest mean absolute percentage error of $3.25 \%$ and the lowest was $23.12 \%$.

Keywords: Decision Support, Sale of Broiler Chicken, Trend Moment

\section{PENDAHULUAN}

Peramalan (Forecasting) adalah suatu kegiatan yang memperkirakan apa yang akan terjadi pada masa yang akan datang dengan mengolah data pada masa lalu yang dibentuk oleh data historis perusahaan. Ramalan adalah sesuatu kegiatan situasi atau kondisi yang diperkirakan akan terjadi pada masa yang akan datang. Peramalan dilakukan dengan memanfaatkan informasi terbaik yang ada pada masa itu, untuk menimbang kegiatan di masa yang akan datang.

Secara umum, peramalan dapat dikelompokkan ke dalam peramalan kuantitatif dan peramalan kualitatif. Peramalan kualitatif adalah peramalan yang didasarkan pada intuisi dan pengalaman empiris, sehingga relatif bersifat subjektif. Untuk situasi yang kompleks, peramalan subjektif sukar dilaksanakan karena keterbatasan otak manusia dalam menganalisis informasi serta hubungan sebab akibat yang mempengaruhi bisnisnya. Jika peramalan kualitatif tersebut dilakukan oleh beberapa orang secara terpisah, hasilnya akan memiliki variasi yang cukup besar. Sebaliknya, jika dilaksanakan secara bersama-sama, kemungkinan tidak diperoleh kesamaan hasil peramalan, atau orang yang berpengaruh pada kelompok yang menentukan hasilnya.

Menurut Sianipar(2014) menjelaskan dalam jurnalnya bahwa: Forecasting (peramalan) merupakan alat bantu yang penting dalam perencanaan yang efektif dan efisien khususnya dalam bidang ekonomi. Dalam organisasi modern mengetahui keadaan yang akan datang tidak saja penting untuk melihat yang baik atau buruk tetapi juga bertujuan untuk melakukan persiapan forecasting.

Tujuan suatu usaha bisnis adalah untuk memperoleh keuntungan, baik itu perusahaan dagang maupun perusahaan jasa. Selain itu, setiap perusahaan sudah menargetkan penjualan yang ingin dicapai setiap hari, bulan atau tahun. Perusahaan membutukan sebuah metode forecasting (ramalan) penjualan yaitu dapat dicari dengan menggunakan tren untuk memperkirakan berapa jumlah penjualan yang kemungkinan terjadi di tahun yang akan datang. Dengan demikian, perusahaan dapat membuat suatu kebijakan atau keputusan yang dilakukan secara tepat untuk mencapai target tersebut. Jika sebuah kebijakan dari seorang manajer tepat maka akan berbanding lurus dengan penjualan meningkat maka perusahan tersebut akan semakin berkembang.

Dengan demikian, forecasting (ramalan) perjualan sangat diperlukan dalam manajemen bisnis guna mengembangkan usaha tersebut, baik bidang jasa maupun dagang. Metode-metode yang digunakan dalam meramal menjadi suatu cara bagaimana manajemen pada akhirnya harus membuat keputusan atau kebijakan yang tepat dalam mengambil suatu tindakan yang berkaitan dengan perusahaan.

Dari wawancara dan data yang ditemui dilapangan CV. Merdeka Adi Perkasa belum menerapkan prediksi untuk penjualan ayam broiler dengan benar. CV. Merdeka Adi Perkasa melakukan penjualan melakukan aktivitas 
penjualan ayam broiler tergantung pada tingkat permintaan konsumen. Artinya perusahaan tetap mendistribusikan berdasarkan volume yang telah ditentukan tetapi perusahaan tetap menambah jumlah volume ayam broiler ke vendor lain apabila permintaan konsumen juga meningkat. Dapat disimpulkan bahwa pimpinan perusahaan tidak menerapkan suatu metode prediksi yang pasti selama perusahaan berjalan. Selama ini perusahaan hanya menerapkan metode perhitungan yang sangat sederhana.

Berdasarkan dari latar belakang yang telah dipaparkan maka penulis tertarik mengadakan penelitian yaitu memprediksi penjualan ayam broiler dimana memprediksi penjualan ayam broiler pada masa mendatang dengan penggunaan data dua tahun terakhir dari Januari 2016 sampai dengan November 2017. Hal ini akan memudahkan pihak yang terkait khususnya CV. Merdeka Adi Perkasa cepat mengambil keputusan yang tepat dalam memprediksi penjualan ayam broiler di masa yang akandatang, sehingga dapat mengurangi permintaan ke vendor lain untuk mencukupi permintaan konsumen yang meningkat.

\section{TEORITIS}

\subsection{Sistem Pendukun Keputusan}

Menurut Moore dan Chang dalam Turban (2007) mendefinisikan "sistem pendukung keputusan sebagai sistem yang memiliki kemampuan dalam mendukung analisis data dan pemodelan keputusan dengan berorientasi pada perencanaan masa depan dan digunakan dalam jangka waktu yang tak tentu”.Sedangkan menurut Little dalam Turban (2007) mendefinisikan bahwa "sistem pendukung keputusan sebagai satu set model berbasis prosedur untuk memproses data dan pertimbangan untuk membantu manajer dalam pengambilan keputusan”.

\subsection{Penjualan}

Penjualan menurut Abdullah dan Tantri (2016 Penjualan adalah bagian dari promosi dan promosi adalah salah satu bagian dari keseluruhan sistem pemasaran.

Menurut Moekjiat dalam jurnal Ratningsih (2017) menjelaskan bahwa "penjualan merupakan sebuah kegiatan yang bertujuan untuk mencari, mempengaruhi dan memberi petunjuk kepada pembeli agar dapat menyesuaikan kebutuhannya dengan produk yang ditawarkan serta mengadakan perjanjian mengenai harga yang menguntungkan bagi kedua belah pihak".

\subsection{Populasi dan Sample}

Menurut Arikunto (2010) menjelaskan bahwa "populasi adalah keseluruhan subjek penelitian”. Sedangkan menurut Sugiyono (2010) populasi adalah "wilayah generalisasi yang terdiri atas obyek atau subyek yang mempunyai kualitas dan karakteristik tertentu yang ditetapkan oleh peneliti untuk dipelajari dan kemudian ditarik kesimpulannya".

Pengertian sampel menurut Sugiyono (2010) "Sampel adalah bagian dari jumlah dan karakteristik yang dimiliki oleh populasi tersebut."

\subsection{Peramalan (Forecasting)}

Menurut Kusuma dalam Sianipar (2010) menjelaskan Forecasting adalah perkiraan tingkat permintaan satu atau lebih produk selama beberapa periode mendatang. Sedangkan Menurut Hani Handoko dalam Sianipar (2010) menjelaskan Forecastingadalah suatu usaha untuk meramalkan keadaan pada masa mendatang melalui pengujian keadaan di masa lalu.

Menurut Riduwan (2010) menjelaskan bahwa: peramalan adalah suatu proses memperkirakan secara sistematis tentangapa yang mungkin terjadi dimasa yang akan datang berdasarkan informasi masa lalu dan sekarang yang dimiliki agar kesalahannya dapat diperkecil. Peramalan tidak memberikan jawaban pasti tentang apa yang akan terjadi, melainkan berusaha mencari pendekatan tentang apa yang akan terjadi sehingga dapat memberikan kontribusi dalam menentukan keputusan yang terbaik. Menurut Arnold dan Chapman dalam jurnal Ratningsih (2017) menyatakan bahwa: Terdapat empat karakteristik peramalan. Adapun karakteristik atau prinsip peramalan tersebut adalah sebagai berikut ini:

1. Peramalan biasanya salah. Peramalan mencoba untuk melihat masa depan yang belum diketahui dan biasanya salah dalam beberapa asumsi atau perkiraan. Kesalahan harus diprediksi dan hal itu tidak dapat dielakkan.

2. Setiap peramalan seharusnya menyertakan estimasi kesalahan (error). Oleh karena peramalan diprediksikan akan menemui kesalahan, pertanyaan sebenarnya adalah seberapa besar kesalahan tersebut. Setiap peramalan seharusnya menyertakan estimasi kesalahan yang dapat di diukur sebagai tingkat kepercayaan, dapat berupa presentase (plus atau minus) dari peramalan sebagai rentang nilai minimum dan maksimum.

3. Peramalan akan lebih akurat untuk kelompok atau grup. Perilaku dari individual item dalam sebuah grup adalah acak bahkan ketika grup tersebut berada dalam keadaan stabil. 
Peramalan lebih akurat untuk jangka waktu yang lebih dekat. Peramalan untuk jangka panjang biasanya akan memiliki tingkat kesalahan yang lebih tinggi, dikarenakan tidak diketahui kejadian kejadian yang akan terjadi dimasa mendatang. Oleh karena itu lebih baik meramalkan untuk jangka waktu yang lebih pendek dengan melakukan pendekatan situasi yang terjadi pada saat peramalan dilakukan.

\subsection{Trend Moment}

Menurut Suharyadi dan Purwanto dalam jurnal Ratningsih (2017 : 43) menyatakan bahwa: Trend adalah suatu gerakan yang cenderung naik atau turun dalam jangka panjang yang diperoleh dari rata-rata perubahan dari waktu ke waktu dan nilainya cukup rata atau mulus (smooth). Trend data berkala bisa berbentuk trend yang meningkat dan menurun secara mulus. Kekuatan yang dapat mempengaruhi trend adalah perubahan populasi, harga, teknologi dan produktivitas.

Metode trend moment menggunakan cara-cara perhitungan statistika dan matematika tertentu untuk mengetahui fungsi garis lurus sebagai pengganti garis patah-patah yang dibentuk oleh data historis perusahaan. Dengan demikian pengaruh unsur subyektif dapat dihindarkan. Persamaan trend dengan metode trend moment adalah seperti pada persamaan berikut ini:

$$
\mathrm{Y}=\mathrm{a}+\mathrm{bX}
$$

Dimana :

$\mathrm{Y}$ : nilai trend ( Peramalan )

a : bilangan konstant

$\mathrm{b}$ : slope atau koefisien kecondongan garis tren

$\mathrm{X}$ : indeks waktu $(\mathrm{x}=0,1,2,3, \ldots, \mathrm{n})$

Metode trend moment berbeda dengan metode lainnya, untuk penentuan data historis $\mathrm{X}$ pada penggunaannyatidak harus berjumlah genap atau ganjil karena nilai parameter $\mathrm{X}$ selalu dimulai dengan nilai 0 sebagai urutan yang pertama. Untuk mencari nilai a dan b pada rumus diatas, digunakan dengan cara matematis dengan penyelesaiannya menggunakan metode substitusi dan metode eleminasi.

$$
\begin{aligned}
& \sum y=a \cdot n+b \cdot \sum x \\
& \sum x y=a \cdot \sum x+b \sum x^{2}
\end{aligned}
$$

Dimana :

$\sum y=$ Jumlah dari data penjulan

$\sum x=$ Jumlah dari periode waktu

$\sum x y=$ Jumlah dari data penjualan dikali dengan periode waktu

$n=$ Jumlah data

Setelah nilai ramalan yang telah diperoleh dari hasil peramalan dengan metode trend moment akan dikoreksi terhadap pengaruh musiman dengan menggunakan indeks musim. Perhitungan indeks musim yaitu:

Indeks musim $=\frac{\text { Rata }- \text { rata permintaan bulan tertentu }}{\text { Rata-rata permintaan perbulan }}$

Untuk mendapatkan hasil ramalan akhir setelah dipengaruhi oleh indeks musim maka akan menggunakan perhitungan sebagai berikut:

$\mathrm{Y} *=$ Indeks Musim x Y

Dimana :

Y* = Hasil ramalan dengan menggunakan metode trend moment yang telah

dipengaruhi oleh indeks musim.

$\mathrm{Y}=$ Hasil ramalan dengan menggunakan trend moment.

\subsection{Simple Moving Average}

Menurut Nasapi dalam Gusdian, dkk (2016 : 99) menjelaskan "Moving Average termaksud dalam time series model yang merupakan metode peramalan kuntitatif dengan menggunakan waktu sebagai dasar peramalan".

Menurut Gaspersz dalam Gusdian, dkk (2016 : 99) menyatakan bahwa "metode Single Moving Average atau metode rata-rata bergerak tunggal menggunakan sejumlah data aktual permintaan yang baru untuk membangkitkan 
nilai ramalan untuk permintaan dimasa yang akan datang”. Metode ini akan efektif diterapkan apabila kita dapat mengasumsikan bahwa permintaan pasar terhadap produk akan tetap stabil sepanjang waktu Metode ini mempunyai dua sifat khusus yaitu untuk membuat forecasting memerlukan data historis dalam jangka waktu tertentu, semakin panjang moving average akan menghasilkan moving average yang semakin halus, secara sistematis moving average adalah:

$$
\begin{aligned}
& \mathrm{St}+1=\frac{X_{t}+X_{t-1}+\ldots X_{t-n+1}}{n} \\
& \text { Keterangan : } \\
& \mathrm{St}+1=\text { Forecast } \text { untuk period ke } \mathrm{t}+1 . \\
& \mathrm{Xt}=\text { Data pada periode } \mathrm{t} . \\
& \mathrm{n}=\text { Jangka waktu Moving averages. }
\end{aligned}
$$

\subsection{Pengukuran Akurasi Peramalan}

Menurut Heizer dan Render (2011:145), jika Ft melambangkan peramalan pada periode t, dan At melambangkan permintaan aktual pada periode t, maka kesalahan peramalan (forecast error) sebagai berikut:

Kesalahan peramalan (forecast error) $=$ permintaan aktual - nilai peramalan

$E_{t}=A_{t}-F_{t}$

1. MAD (Mean Absolute Deviation)

MAD merupakan rata-rata kesalahan mutlak selama periode tertentu tanpa memperhatikan apakah hasil peramalan lebih besar atau lebih kecil dibandingkan kenyataannya. Secara matematis, MAD dirumuskan sebagai berikut:

$M A D=\sum\left|\frac{A_{t}-F_{t}}{n}\right|$

Keterangan:

$A_{t}=$ permintaan aktual pada periode-t,

$F_{t}=$ peramalan permintaan pada periode-t,

$\mathrm{n}=$ jumlah periode peramalan yang terlibat

\section{MSE (Mean Square Error)}

MSE dihitung dengan menjumlahkan kuadrat semua kesalahan peramalan pada setiap periode dan membaginya dengan jumlah periode peramalan. Secara matematis, MSE dirumuskan sebagai berikut:

$M S E=\sum \frac{\left(A_{t}-F_{t}\right)^{2}}{n}$

\section{MAPE (Mean Percentage Error)}

MAPE biasanya lebih berarti membandingkan MAD karena MAPE menyatakan persentase kesalahan hasil peramalan terhadap permintaan aktual selama periode tertentu yang akan memberikan informasi persentase kesalahan. Secara matematis, MAPE dirumuskan sebagai berikut:

$M A P E=\sum\left|\frac{\left(A_{t}-F_{t}\right)}{A_{t}}\right| x 100 \%$

\section{ANALISA DAN PEMBAHASAN}

Pada bab ini dideskripsikan hasil penelitian yang telah dilakukan di CV. Merdeka Adi Perkasa, melalui proses penelitian dengan wawancara serta meminta data penjualan bulananayam broiler dari november 2016 hingga oktober 2017. Data penjualan tersebut yang merupakan proses analisis kebutuhan dari penelitian ini yang bertujuan untuk memprediksi penjualan ayam broiler pada CV. Merdeka Adi Perkasa untuk beberapa bulan kedepan. Sampel dalam penelitian ini adalah data penjualan ayam broiler yang diberikan CV. Merdeka Adi Perkasa.

Tahapan penelitian tersebut akan diuraikan menggunakan metode trend moment dan metode simple moving average secara manual.Deskripsi data penelitian tersebut menggunakan data penjualan bulanan ayam broiler pada CV. Merdeka Adi Perkasa rentang waktu november 2016 hingga oktober 2017.

\section{A. Analisis Kebutuhan}

Analisis kebutuhan ini dilakukan dengan mengolah data penjualan ayam broiler yang diterima dari CV. Merdeka Adi Perkasaterlampir pada lampiran A.1 yang bertujuan untuk menelusuri faktor - faktor yang dijadikan 
bahan untuk proses menentukan prediksi penjualan ayam broiler. Data penjualan ayam broilerakan diolah menggunakan metode trend moment dan simple moving averange.

Berikut merupakan data penjualan bulanan ayam broiler CV. Merdeka Adi Perkasa bulan november 2016 hingga oktober 2017.

\begin{tabular}{cc}
\multicolumn{2}{c}{ Tabel 1. Data Penjualan Ayam Broiler } \\
\hline Bulan (Skala Waktu) & Penjualan (Y) \\
\hline November 2016 & 168.313 \\
Desember 2016 & 186.710 \\
Januari 2017 & 115.086 \\
Februari 2017 & 161.973 \\
Maret 2017 & 141.126 \\
April 2017 & 179.157 \\
Mei 2017 & 209.084 \\
Juni 2017 & 164.793 \\
Juli 2017 & 159.797 \\
Agustus 2017 & 158.279 \\
September 2017 & 139.841 \\
Oktober 2017 & 137.103 \\
\hline
\end{tabular}

Sumber : CV. Merdeka Adi Perkasa(2017)

Data diatas diolah untuk menentukan prediksi penjualan ayam broiler menggunakan metode trend moment dengan menginputkan nilai $\mathrm{x}$, $\mathrm{xy}$ dan $\mathrm{x}^{2}$ seperti tabel di bawah ini:

Tabel 2. Data Penjualan Ayam Broiler dengan nilai $\mathrm{x}, \mathrm{xy}$ dan $\mathrm{x}^{2}$

\begin{tabular}{ccccc}
\hline Bulan (Skala Waktu) & Penjualan $(\mathbf{Y})$ & $\mathbf{X}$ & $\mathbf{X Y}$ & $\mathbf{X}^{\mathbf{2}}$ \\
\hline November 2016 & 168.313 & 0 & 0 & 0 \\
Desember 2016 & 186.710 & 1 & 186.710 & 1 \\
Januari 2017 & 115.086 & 2 & 230.172 & 4 \\
Februari 2017 & 161.973 & 3 & 485.919 & 9 \\
Maret 2017 & 141.126 & 4 & 564.504 & 16 \\
April 2017 & 179.157 & 5 & 895.785 & 25 \\
Mei 2017 & 209.084 & 6 & 1.254 .504 & 36 \\
Juni 2017 & 164.793 & 7 & 1.153 .551 & 49 \\
Juli 2017 & 159.797 & 8 & 1.278 .376 & 64 \\
Agustus 2017 & 158.279 & 9 & 1.424 .511 & 81 \\
September 2017 & 139.841 & 10 & 1.398 .410 & 100 \\
Oktober 2017 & 137.103 & 11 & 1.508 .133 & 121 \\
\hline
\end{tabular}

Kemudian data penjualan di atas akan diolah menggunakan metode trend momentsetelah hasil prediksi ditemukan maka nilai prediksi akan dibandingkan dengan nilai penjualan aktual untuk mendapatkan nilai ketepatan metode menggunakan metode Mean Absolute Percentage Error. Data yang akan dicari nilai MAPE nya dari februari 2017 hingga oktober 2017 dengan perhitungan sebagai berikut :

Rumus metode Trend Moment adalah :

$$
\mathrm{Y}=\mathrm{a}+\mathrm{b}(\mathrm{x})
$$

Dalam mencari koefisien a dan b menggunakan persamaan :

$$
\begin{gathered}
\sum y=a \cdot n+b \cdot \sum x \\
\sum x y=a \cdot \sum x+b \sum x^{2}
\end{gathered}
$$

Data yang diujikan adalah data penjualan bulan februari 2017 maka $n=3$ dan selanjutnya terhadap persamaan yang terbentuk dapat dicari penyelesaiannya melalui metode eliminasi ataupun metode substitusi.

(I) $470.109=3 a+b(3) \quad[x 1]$ 


$$
\text { (II) } \begin{aligned}
416.882 & =3 \mathrm{a}+\mathrm{b}(5) \\
470.109 & =3 \mathrm{a}+3 \mathrm{~b} \\
416.882 & =3 \mathrm{a}+5 \mathrm{~b} \\
53.227 & =-2 \mathrm{~b} \\
\hline \mathrm{b} & =-26.614
\end{aligned}
$$

Substitusikan

$$
\begin{array}{ll}
\mathrm{b} & =-26.614 \longrightarrow(\mathrm{I}) \\
470.109 & =3 \mathrm{a}+3 \mathrm{~b} \\
3 \mathrm{a} & =470.109-(-79.842)=549.951 \\
\mathrm{a} & =549.951 / 3 \\
\mathrm{a} & =183.317
\end{array}
$$

Maka, persamaan trend-nya

$$
\begin{array}{ll}
\mathrm{Y} & =\mathrm{a}+\mathrm{b}(\mathrm{x}) \\
\mathrm{Y} & =183.317+(-26.614)(\mathrm{x})
\end{array}
$$

Dengan demikian, Forecastx untuk bulan februari 2017 adalah 3.

$$
\begin{aligned}
& \mathrm{Y}=183.317+(-26.614)(3) \\
& \mathrm{Y}=\mathbf{1 0 3 . 4 7 5} \text { (Forecasting) }
\end{aligned}
$$

Data Aktual Penjualan = $\mathbf{1 6 1 . 9 7 3}$

Kemudian setelah mendapatkan hasil ramalan maka akan di bandingkan dengan data aktual penjualan dengan persamaan metode MAPE (Mean Absolute Percentage Error) untuk melihat ketepatan metode :

$$
\begin{aligned}
M A P E= & \sum\left|\frac{\left(A_{t}-F_{t}\right)}{A_{t}}\right| \times 100 \% \\
M A P E= & \left|\left(\frac{161.973-103.475}{161.973}\right)\right| \times 100 \% \\
M A P E= & \left|\left(\frac{58.498}{161.973}\right)\right| \times 100 \% \\
M A P E= & (0.3612) \times 100 \% \\
& M A P E=\mathbf{3 6 . 1 2} \%
\end{aligned}
$$

Selanjutnya data yang diujikan adalah data penjualan bulan maret 2017 maka $n=4$ dan selanjutnya terhadap persamaan yang terbentuk dapat dicari penyelesaiannya melalui metode eliminasi ataupun metode substitusi.

$$
\begin{aligned}
& \text { (I) } 632.082=4 \mathrm{a}+\mathrm{b}(6) \quad[\mathrm{x} 3] \\
& \text { (II) } 902.801=6 \mathrm{a}+\mathrm{b}(14) \quad[\mathrm{x} 2] \\
& 1.896 .246=12 \mathrm{a}+18 \mathrm{~b} \\
& 1.805 .602=12 a+28 b \\
& \underline{90.644=-10 \mathrm{~b}} \\
& \mathrm{~b}=-9.064
\end{aligned}
$$

Substitusikan

$$
\begin{array}{lll}
\mathrm{b} & =-9.064- & \rightarrow(\mathrm{I}) \\
632.082 & =4 \mathrm{a}+6 \mathrm{~b} \\
4 \mathrm{a} & =632.082-(-54.384)=686.466 \\
\mathrm{a} & =686.466 / 4 \\
\mathrm{a} & =171.617
\end{array}
$$

Maka, persamaan trend-nya $\mathrm{a}+\mathrm{b}(\mathrm{x})$ :

$$
\mathrm{Y}=171.617+(-9.064)(\mathrm{x})
$$

Dengan demikian, Forecastx untuk bulan maret 2017 adalah4

$$
\begin{aligned}
& \mathrm{Y}=171.617+(-9.064)(4) \\
& \mathrm{Y}=\mathbf{1 3 5 . 3 6 1} \text { (Forecasting) }
\end{aligned}
$$


Data Aktual Penjualan $=\mathbf{1 4 1 . 1 2 6}$

Kemudian setelah mendapatkan hasil ramalan maka akan di bandingkan dengan data aktual penjualan dengan persamaan metode MAPE (Mean Absolute Percentage Error) untuk melihat ketepatan metode :

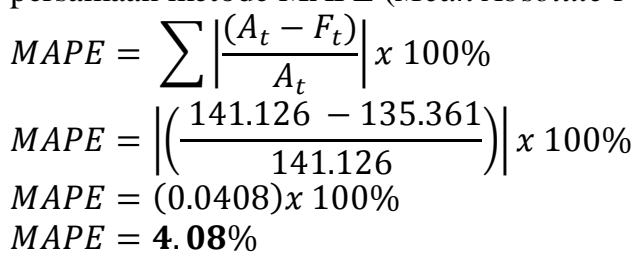

Selanjutnya data yang diujikan adalah data penjualan bulan april 2017 maka $n=5$ dan selanjutnya terhadap persamaan yang terbentuk dapat dicari penyelesaiannya melalui metode eliminasi ataupun metode substitusi.

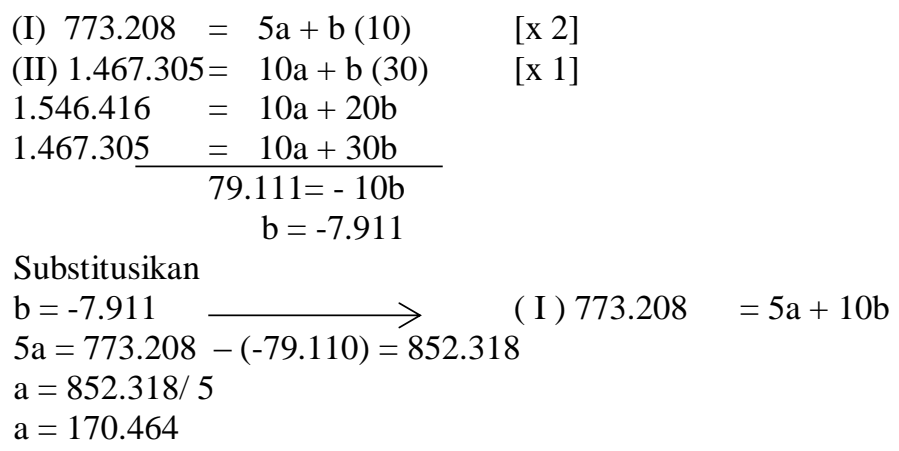

Maka, persamaan trend-nya

$\mathrm{a}+\mathrm{b}(\mathrm{x})$ :

$\mathrm{Y}=170.464+(-7.911)(\mathrm{x})$

Dengan demikian, Forecastx untuk bulan april 2017 adalah5

$$
\begin{aligned}
& Y=170.464+(-7.911)(5) \\
& Y=130.909 \text { (Forecasting) }
\end{aligned}
$$

Data Aktual Penjualan = 179.157

Kemudian setelah mendapatkan hasil ramalan maka akan di bandingkan dengan data aktual penjualan dengan persamaan metode MAPE (Mean Absolute Percentage Error) untuk melihat ketepatan metode :

$$
\begin{aligned}
M A P E & =\sum\left|\frac{\left(A_{t}-F_{t}\right)}{A_{t}}\right| \times 100 \% \\
M A P E & =\left|\left(\frac{179.157-130.909}{179.157}\right)\right| \times 100 \% \\
M A P E & =(0.2693) \times 100 \% \\
M A P E & =\mathbf{2 6 . 9 3} \%
\end{aligned}
$$

Selanjutnya data yang diujikan adalah data penjualan bulan mei 2017 maka $n=6$ dan selanjutnya terhadap persamaan yang terbentuk dapat dicari penyelesaiannya melalui metode eliminasi ataupun metode substitusi.

$$
\begin{array}{cc}
\text { (I) } 952.365 \quad=6 a+b(15) & \text { [x 5] } \\
\text { (II) } 2.363 .090=15 a+b(55) & \text { [x 2] } \\
4.761 .825=30 a+75 b & \\
4.726 .180=30 a+110 b & \\
35.645=-35 b & \\
\hline b= & -1.018
\end{array}
$$

Substitusikan

$$
\begin{aligned}
& \mathrm{b}=-1.018 \longrightarrow \text { (I) } 952.365=6 \mathrm{a}+15 \mathrm{~b} \\
& 6 \mathrm{a}=952.365-(-15.270)=967.635 \\
& \mathrm{a}=967.635 / 6 \\
& \mathrm{a}=161.273 \\
& \text { Maka, persamaan trend-nya }
\end{aligned}
$$




$$
\begin{aligned}
& \mathrm{a}+\mathrm{b}(\mathrm{x}): \\
& \mathrm{Y}=161.273+(-1.018)(\mathrm{x})
\end{aligned}
$$

Dengan demikian, Forecastx untuk bulan mei 2017 adalah6

$\mathrm{Y}=161.273+(-1.018)(6)$

$\mathrm{Y}=\mathbf{1 5 5 . 1 6 5}$ (Forecasting)

Data Aktual Penjualan $=\mathbf{2 0 9 . 0 8 4}$

Kemudian setelah mendapatkan hasil ramalan maka akan di bandingkan dengan data aktual penjualan dengan persamaan metode MAPE (Mean Absolute Percentage Error) untuk melihat ketepatan metode :

$$
\begin{aligned}
M A P E & =\sum\left|\frac{\left(A_{t}-F_{t}\right)}{A_{t}}\right| \times 100 \% \\
M A P E & =\left|\left(\frac{209.084-155.165}{209.084}\right)\right| \times 100 \% \\
M A P E & =(0.2579) \times 100 \% \\
M A P E & =\mathbf{2 5 . 7 9} \%
\end{aligned}
$$

Selanjutnya data yang diujikan adalah data penjualan bulan juni 2017 maka $n=7$ dan selanjutnya terhadap persamaan yang terbentuk dapat dicari penyelesaiannya melalui metode eliminasi ataupun metode substitusi.

$$
\begin{aligned}
& \text { (I) } 1.161 .449=7 \mathrm{a}+\mathrm{b}(21) \quad[\mathrm{x} 3] \\
& \text { (II) } 3.617 .594=21 \mathrm{a}+\mathrm{b}(91) \quad \text { [x } 1] \\
& 3.484 .347=21 a+63 b \\
& 3.617 .594=21 \mathrm{a}+91 \mathrm{~b} \\
& \begin{aligned}
-133.247 & =-28 b \\
b & =4.759
\end{aligned}
\end{aligned}
$$

Substitusikan

$$
1.161 .449=7 \mathrm{a}+21 \mathrm{~b}
$$

$7 \mathrm{a}=1.161 .449-99.939=1.061 .510$

$\mathrm{a}=1.061 .510 / 7$

$\mathrm{a}=151.644$

$$
\begin{aligned}
& \text { Maka, persamaan trend-nya } \\
& \mathrm{a}+\mathrm{b}(\mathrm{x}): \\
& \mathrm{Y}=151.644+4.759(\mathrm{x})
\end{aligned}
$$

Dengan demikian, Forecastx untuk bulan juni 2017 adalah 7

$$
\begin{aligned}
& \mathrm{Y}=151.644+4.759(7) \\
& \mathrm{Y}=\mathbf{1 8 4 . 9 5 7} \text { (Forecasting) }
\end{aligned}
$$

Data Aktual Penjualan = 164.793

Kemudian setelah mendapatkan hasil ramalan maka akan di bandingkan dengan data aktual penjualan dengan persamaan metode MAPE (Mean Absolute Percentage Error) untuk melihat ketepatan metode :

$$
\begin{aligned}
M A P E & =\sum\left|\frac{\left(A_{t}-F_{t}\right)}{A_{t}}\right| \times 100 \% \\
M A P E & =\left|\left(\frac{164.793-184.957}{164.793}\right)\right| \times 100 \% \\
M A P E & =(0.1224) \times 100 \% \\
M A P E & =\mathbf{1 2 . 2 4} \%
\end{aligned}
$$

Selanjutnya data yang diujikan adalah data penjualan bulan juli 2017 maka $n=8$ dan selanjutnya terhadap persamaan yang terbentuk dapat dicari penyelesaiannya melalui metode eliminasi ataupun metode substitusi.
(I) $1.326 .242=8 \mathrm{a}+\mathrm{b}(28)$ [x 7]
(II) $4.771 .145=28 \mathrm{a}+\mathrm{b}(140)$
$9.283 .694=56 a+196 b$
$9.542 .290=56 \mathrm{a}+280 \mathrm{~b}$
$-258.596=-84 b$ 
Substitusikan

$$
\mathrm{b}=3.079
$$

$$
\begin{aligned}
\mathrm{b} & =3.079 \longrightarrow \\
1.326 .242 & =8 \mathrm{a}+28 \mathrm{~b} \\
8 \mathrm{a} & =1.326 .242-86.212=1.240 .030 \\
\mathrm{a} & =1.240 .030 / 8 \\
\mathrm{a} & =155.004
\end{aligned}
$$

Maka, persamaan trend-nya

$$
\begin{aligned}
& \mathrm{a}+\mathrm{b}(\mathrm{x}): \\
& \mathrm{Y}=155.004+3.079(\mathrm{x})
\end{aligned}
$$

Dengan demikian, Forecastx untuk bulan juli 2017 adalah 8

$$
\begin{aligned}
& \mathrm{Y}=155.004+3.079(8) \\
& \mathrm{Y}=\mathbf{1 7 9 . 6 3 6}(\text { Forecasting })
\end{aligned}
$$

Data Aktual Penjualan $=\mathbf{1 5 9 . 7 9 7}$

Kemudian setelah mendapatkan hasil ramalan maka akan di bandingkan dengan data aktual penjualan dengan persamaan metode MAPE (Mean Absolute Percentage Error) untuk melihat ketepatan metode :

$$
\begin{aligned}
M A P E & =\sum\left|\frac{\left(A_{t}-F_{t}\right)}{A_{t}}\right| \times 100 \% \\
M A P E & =\left|\left(\frac{159.797-179.636}{159.797}\right)\right| \times 100 \% \\
M A P E & =(0.1242) \times 100 \% \\
M A P E & =\mathbf{1 2 . 4 2} \%
\end{aligned}
$$

Selanjutnya data yang diujikan adalah data penjualan bulan agustus 2017 maka $n=9$ dan selanjutnya terhadap persamaan yang terbentuk dapat dicari penyelesaiannya melalui metode eliminasi ataupun metode substitusi.

$$
\begin{array}{rlrl}
\text { (I) } 1.486 .039 & =9 \mathrm{a}+\mathrm{b}(36) & & {[\mathrm{x} 4]} \\
\text { (II) } 6.049 .521 & =36 \mathrm{a}+\mathrm{b}(204) & & {[\mathrm{x} 1]} \\
5.944 .156 & =36 \mathrm{a}+144 \mathrm{~b} & \\
6.049 .521 & =36 \mathrm{a}+204 \mathrm{~b} & \\
-105.365 & =-60 \mathrm{~b} & \\
\mathrm{~b} & =1.756 & \text { ( I }) \\
\text { Substitusikan } & \\
\mathrm{b} & =1.756 \rightarrow & \\
1.486 .039 & =9 \mathrm{a}+36 \mathrm{~b} & \\
9 \mathrm{a} & =1.486 .039-63.216=1.422 .823 \\
\mathrm{a} & =1.422 .823 / 9 \\
\mathrm{a} & =158.091
\end{array}
$$

Maka, persamaan trend-nya

$$
\begin{aligned}
& \mathrm{a}+\mathrm{b}(\mathrm{x}): \\
& \mathrm{Y}=158.091+1.756(\mathrm{x})
\end{aligned}
$$

Dengan demikian, Forecastx untuk bulan agustus 2017 adalah 9

$$
\begin{aligned}
& Y=158.091+1.756(9) \\
& Y=173.895 \text { (Forecasting) }
\end{aligned}
$$

Data Aktual Penjualan $=\mathbf{1 5 8 . 2 7 9}$

Kemudian setelah mendapatkan hasil ramalan maka akan di bandingkan dengan data aktual penjualan dengan persamaan metode MAPE (Mean Absolute Percentage Error) untuk melihat ketepatan metode :

$$
\begin{aligned}
M A P E & =\sum\left|\frac{\left(A_{t}-F_{t}\right)}{A_{t}}\right| \times 100 \% \\
M A P E & =\left|\left(\frac{158.279-173.895}{158.279}\right)\right| \times 100 \% \\
M A P E & =(0.0987) \times 100 \% \\
M A P E & =\mathbf{9 . 8 7} \%
\end{aligned}
$$

Selanjutnya data yang diujikan adalah data penjualan bulan september 2017 maka $n=10$ dan selanjutnya terhadap persamaan yang terbentuk dapat dicari penyelesaiannya melalui metode eliminasi ataupun metode substitusi.
(I) $1.644 .318=10 \mathrm{a}+\mathrm{b}(45)$ 


$$
\text { (II) } \begin{aligned}
7.474 .032 & =45 \mathrm{a}+\mathrm{b}(285) \\
14.798 .862 & =36 \mathrm{a}+405 \mathrm{~b} \\
14.948 .064 & =36 \mathrm{a}+570 \mathrm{~b} \\
-149.202 & =-165 \mathrm{~b}
\end{aligned}
$$

Substitusikan

$$
\begin{aligned}
\mathrm{b} & =904 \longrightarrow \\
1.644 .318 & =10 \mathrm{a}+45 \mathrm{~b}
\end{aligned}
$$$$
10 \mathrm{a}=1.644 .318-40.680=1.603 .638
$$$$
\mathrm{a}=1.603 .638 / 10
$$$$
\mathrm{a}=160.364
$$

Maka, persamaan trend-nya

$$
\begin{aligned}
& \mathrm{a}+\mathrm{b}(\mathrm{x}): \\
& \mathrm{Y}=160.364+904(\mathrm{x})
\end{aligned}
$$

Dengan demikian, Forecastx untuk bulan september 2017 adalah 10

$\mathrm{Y}=160.364+904(10)$

$\mathrm{Y}=\mathbf{1 6 9 . 4 0 4}($ Forecasting)

Data Aktual Penjualan $=\mathbf{1 3 9 . 8 4 1}$

Kemudian setelah mendapatkan hasil ramalan maka akan di bandingkan dengan data aktual penjualan dengan persamaan metode MAPE (Mean Absolute Percentage Error) untuk melihat ketepatan metode :

$$
\begin{aligned}
M A P E & =\sum\left|\frac{\left(A_{t}-F_{t}\right)}{A_{t}}\right| \times 100 \% \\
M A P E & =\left|\left(\frac{139.841-169.404}{139.841}\right)\right| \times 100 \% \\
M A P E & =(0.2114) \times 100 \% \\
M A P E & =\mathbf{2 1 . 1 4} \%
\end{aligned}
$$

Selanjutnya data yang diujikan adalah data penjualan bulan oktober 2017 maka $n=11$ dan selanjutnya terhadap persamaan yang terbentuk dapat dicari penyelesaiannya melalui metode eliminasi ataupun metode substitusi.

$$
\begin{aligned}
& \text { (I) } 1.784 .159=11 \mathrm{a}+\mathrm{b}(55) \quad[\mathrm{x} 5] \\
& \text { (II) } 8.872 .442=55 \mathrm{a}+\mathrm{b}(385) \quad \text { [x 1] } \\
& 8.920 .795=55 a+275 b \\
& 8.872 .442=55 \mathrm{a}+385 \mathrm{~b} \\
& 48.353=-110 \mathrm{~b} \\
& b=-440
\end{aligned}
$$

Substitusikan

$$
\begin{aligned}
\mathrm{b} & =-440 \longrightarrow \\
1.784 .159 & =11 \mathrm{a}+55 \mathrm{~b} \\
11 \mathrm{a} & =1.784 .159-(-24.200)=1.808 .359 \\
\mathrm{a} & =1.808 .359 / 11 \\
\mathrm{a} & =164.396
\end{aligned}
$$

Maka, persamaan trend-nya

$$
\begin{aligned}
& \mathrm{a}+\mathrm{b}(\mathrm{x}): \\
& \mathrm{Y}=164.396+(-440)(\mathrm{x}) \\
& \text { Dengan demikian, Forecast } \mathrm{x} \text { untuk bulan oktober } 2017 \text { adalah } 11 \\
& \mathrm{Y}=164.396+(-440)(11) \\
& \mathrm{Y}=\mathbf{1 5 9 . 5 5 6}(\text { Forecasting }) \\
& \text { Data Aktual Penjualan }=\mathbf{1 3 7 . 1 0 3}
\end{aligned}
$$

Kemudian setelah mendapatkan hasil ramalan maka akan di bandingkan dengan data aktual penjualan dengan persamaan metode MAPE (Mean Absolute Percentage Error) untuk melihat ketepatan metode :

$$
\begin{aligned}
M A P E & =\sum\left|\frac{\left(A_{t}-F_{t}\right)}{A_{t}}\right| \times 100 \% \\
M A P E & =\left|\left(\frac{137.103-159.556}{137.103}\right)\right| \times 100 \% \\
M A P E & =(0.1637) \times 100 \% \\
M A P E & =\mathbf{1 6 . 3 7 \%}
\end{aligned}
$$


Tabel 3. Hasil Metode Trend Moment

\begin{tabular}{ccccccc}
\hline $\begin{array}{c}\text { Bulan (Skala } \\
\text { Waktu) }\end{array}$ & Penjualan (Y) & $\mathbf{X}$ & $\mathbf{X Y}$ & $\mathbf{X}^{\mathbf{2}}$ & Ramalan & MAPE \\
\hline November 2016 & 168.313 & 0 & 0 & 0 & - & - \\
Desember 2016 & 186.710 & 1 & 186.710 & 1 & - & - \\
Januari 2017 & 115.086 & 2 & 230.172 & 4 & - & - \\
Februari 2017 & 161.973 & 3 & 485.919 & 9 & 103.475 & $36,12 \%$ \\
Maret 2017 & 141.126 & 4 & 564.504 & 16 & 135.361 & $4,08 \%$ \\
April 2017 & 179.157 & 5 & 895.785 & 25 & 130.909 & $26,93 \%$ \\
Mei 2017 & 209.084 & 6 & 1.254 .504 & 36 & 155.165 & $25,79 \%$ \\
Juni 2017 & 164.793 & 7 & 1.153 .551 & 49 & 184.957 & $12,24 \%$ \\
Juli 2017 & 159.797 & 8 & 1.278 .376 & 64 & 179.636 & $12,42 \%$ \\
Agustus 2017 & 158.279 & 9 & 1.424 .511 & 81 & 173.895 & $9,87 \%$ \\
September 2017 & 139.841 & 10 & 1.398 .410 & 100 & 169.404 & $21,14 \%$ \\
Oktober 2017 & 137.103 & 11 & 1.508 .133 & 121 & 159.556 & $16,37 \%$ \\
\hline \multicolumn{7}{c}{ Sumber : Hasil Penelitian $(2017)$} \\
\end{tabular}

Setelah hasil dari metode diketahui maka diubah ke dalam bentuk grafik membandingkan penjualan aktual dengan ramalan menggunakan metode trend moment.

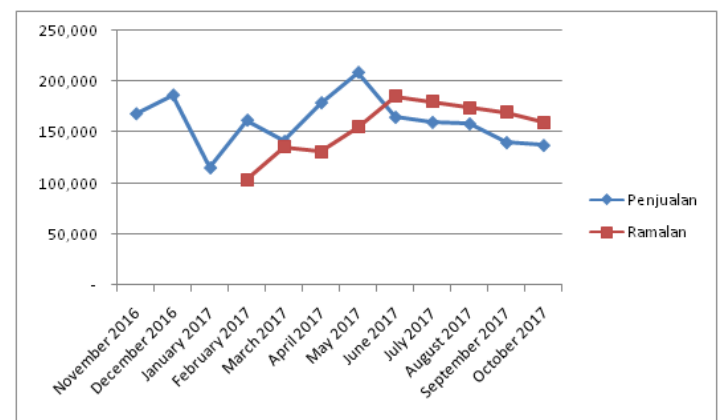

Gambar 1. Grafik Penj. Aktual dan Ramalan Metode Trend Moment Sumber : Hasil Penelitian (2017)

Dengan hasil diatas diperoleh kesimpulan metode trend moment memiliki tingka terror dengan meniliki dari hasil MAPE tertinggi dengan keakurasian sebesar $4.08 \%$ dan terendah dengan keakurasian sebesar $36.12 \%$.Selanjutnya data penjualan yang di paparkan pada table IV.1 akan diolah kembali menggunaka nmetode simple moving average sebagai nilai pembanding dengan metode sebelumnya dengan perhitungannya adalah sebagai berikut : Metode simple moving average menggunakan persamaan

$$
\mathrm{St}+1=\frac{X_{t}+X_{t-1}+\ldots X_{t-n+1}}{n} \text {. }
$$

Data yang diujikan adalah data penjualan bulan februari 2017 dengan amatan 3 bulan sebelumnya :

Februari

$$
\begin{gathered}
2017=\frac{168.313+186.710+115.086}{3}=156.703 \text { (Forecasting) } \\
\text { Data Aktual Penjualan }=\mathbf{1 6 1 . 9 7 3}
\end{gathered}
$$

Kemudian setelah mendapatkan hasil ramalan maka akan dibandingkan dengan data aktual penjualan dengan persamaan metode MAPE (Mean Absolute Percentage Error) untuk melihat ketepatan metode :

$$
\begin{aligned}
& M A P E=\sum\left|\frac{\left(A_{t}-F_{t}\right)}{A_{t}}\right| \times 100 \% \\
& M A P E=\left|\left(\frac{161.973-156.703}{161.973}\right)\right| \times 100 \% \\
& M A P E=\left|\left(\frac{15.539}{161.973}\right)\right| \times 100 \% \\
& M A P E=(0,0325) \times 100 \%
\end{aligned}
$$


Selanjutnya data yang diujikan adalah data penjualan bulan maret 2017 dengan amatan 3 bulan sebelumnya : Maret

$$
\begin{gathered}
2017=\frac{186.710+115.086+161.973}{3}=154.590(\text { Forecasting }) \\
\text { Data Aktual Penjualan }=\mathbf{1 4 1 . 1 2 6}
\end{gathered}
$$

Kemudian setelah mendapatkan hasil ramalan maka akan di bandingkan dengan data aktual penjualan dengan persamaan metode MAPE (Mean Absolute Percentage Error) untuk melihat ketepatan metode :

$$
\begin{aligned}
M A P E & =\sum\left|\frac{\left(A_{t}-F_{t}\right)}{A_{t}}\right| \times 100 \% \\
M A P E & =\left|\left(\frac{141.126-154.590}{141.126}\right)\right| \times 100 \% \\
M A P E & =(0,0954) \times 100 \% \\
M A P E & =\mathbf{9 . 5 4} \%
\end{aligned}
$$

Selanjutnya data yang diujikan adalah data penjualan bulan april 2017 dengan amatan 3 bulan sebelumnya:

$$
2017=\frac{115.086+161.973+141.126}{3}=139.395 \text { (Forecasting) }
$$

Data Aktual Penjualan $=\mathbf{1 7 9 . 1 5 7}$

Kemudian setelah mendapatkan hasil ramalan maka akan di bandingkan dengan data aktual penjualan dengan persamaan metode MAPE (Mean Absolute Percentage Error) untuk melihat ketepatan metode :

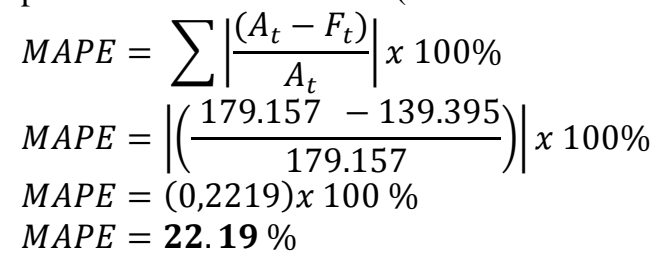

Selanjutnya data yang diujikan adalah data penjualan bulan mei 2017 denganamatan 3 bulansebelumnya :

$$
\text { Mei } 2017=\frac{161.973+141.126+179.157}{3}=160.752 \text { (Forecasting) }
$$

Data Aktual Penjualan $=\mathbf{2 0 9 . 0 8 4}$

Kemudian setelah mendapatkan hasil ramalan maka akan di bandingkan dengan data aktual penjualan dengan persamaan metode MAPE (Mean Absolute Percentage Error) untuk melihat ketepatan metode :

$$
\begin{aligned}
M A P E & =\sum\left|\frac{\left(A_{t}-F_{t}\right)}{A_{t}}\right| \times 100 \% \\
M A P E & =\left|\left(\frac{209.084-160.752}{209.084}\right)\right| \times 100 \% \\
M A P E & =(0,2312) \times 100 \% \\
M A P E & =23.12 \%
\end{aligned}
$$

Selanjutnya data yang diujikan adalah data penjualan bulan juni 2017 dengan amatan 3 bulan sebelumnya :

$$
\begin{aligned}
& \text { Juni } \\
& 2017=\frac{141.126+179.157+209.084}{3}=176.456(\text { Forecasting })
\end{aligned}
$$

Data Aktual Penjualan $=\mathbf{1 6 4 . 7 9 3}$

Kemudian setelah mendapatkan hasil ramalan maka akan di bandingkan dengan data aktual penjualan dengan persamaan metode MAPE (Mean Absolute Percentage Error) untuk melihat ketepatan metode :

$$
\begin{aligned}
& M A P E=\sum\left|\frac{\left(A_{t}-F_{t}\right)}{A_{t}}\right| \times 100 \% \\
& M A P E=\left|\left(\frac{164.793-176.456}{164.793}\right)\right| \times 100 \% \\
& M A P E=(0,0708) \times 100 \%
\end{aligned}
$$


Selanjutnya data yang diujikan adalah data penjualan bulan juli 2017 denganamatan 3 bulansebelumnya :

$$
\text { Juli }
$$

$$
2017=\frac{179.157+209.084+164.793}{3}=184.345 \text { (Forecasting) }
$$

Data Aktual Penjualan $=\mathbf{1 5 9 . 7 9 7}$

Kemudian setelah mendapatkan hasil ramalan maka akan di bandingkan dengan data aktual penjualan dengan persamaan metode MAPE (Mean Absolute Percentage Error) untuk melihat ketepatan metode :

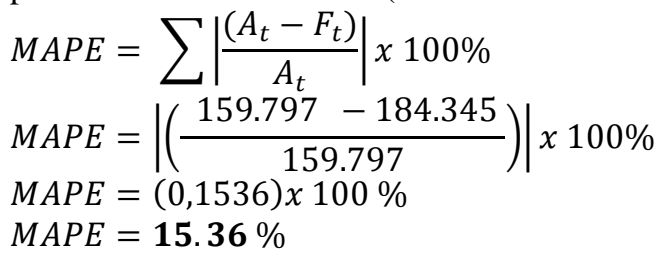

Selanjutnya data yang diujikan adalah data penjualan bulan agustus 2017 dengan amatan 3 bulan sebelumnya : Agustus $2017=\frac{209.084+164.793+159.797}{3}=177.891$ (Forecasting)

Data Aktual Penjualan $=\mathbf{1 5 8 . 2 7 9}$

Kemudian setelah mendapatkan hasil ramalan maka akan di bandingkan dengan data aktual penjualan dengan persamaan metode MAPE (Mean Absolute Percentage Error) untuk melihat ketepatan metode :

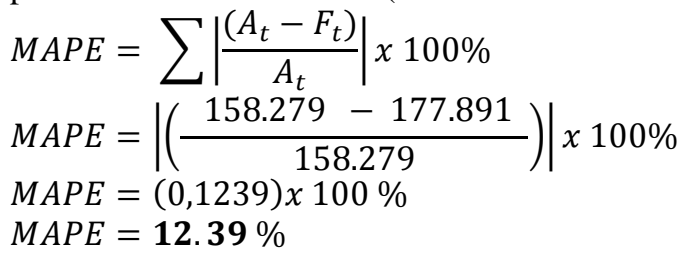

Selanjutnya data yang diujikan adalah data penjualan bulan september 2017 dengan amatan 3 bulan sebelumnya : September $2017=\frac{164.793+159.797+158.279}{3}=160.956$ (Forecasting)

Data Aktual Penjualan $=\mathbf{1 3 9 . 8 4 1}$

Kemudian setelah mendapatkan hasil ramalan maka akan di bandingkan dengan data aktual penjualan dengan persamaan metode MAPE (Mean Absolute Percentage Error) untuk melihat ketepatan metode :

$M A P E=\sum\left|\frac{\left(A_{t}-F_{t}\right)}{A_{t}}\right| x 100 \%$

$M A P E=\left|\left(\frac{139.841-160.956}{139.841}\right)\right| x 100 \%$

$M A P E=(0,1510) \times 100 \%$

$M A P E=15.10 \%$

Selanjutnya data yang diujikan adalah data penjualan bulan oktober 2017 denganamatan 3 bulansebelumnya :

Oktober $2017=\frac{159.797+158.279+139.841}{3}=$

Data Aktual Penjualan $=\mathbf{1 3 7 . 1 0 3}$

Kemudian setelah mendapatkan hasil ramalan maka akan di bandingkan dengan data aktual penjualan dengan persamaan metode MAPE (Mean Absolute Percentage Error) untuk melihat ketepatan metode :

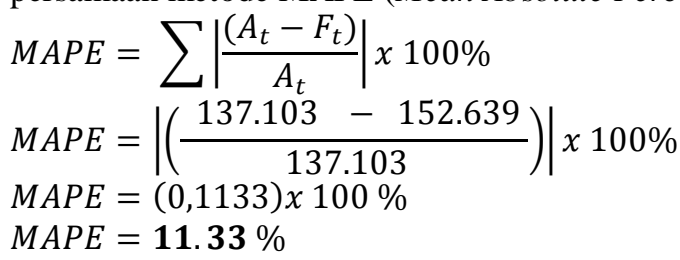


Tabel 4. Hasil metode Simple Moving Average

\begin{tabular}{lccc}
\hline \multicolumn{1}{c}{ Bulan (Skala Waktu) } & Penjualan & Ramalan Simple Moving & MAPE \\
\hline November 2016 & 168.313 & - & - \\
Desember 2016 & 186.710 & - & - \\
Januari 2017 & 115.086 & - & - \\
Februari 2017 & 161.973 & 156.703 & $3,25 \%$ \\
Maret 2017 & 141.126 & 154.590 & $9,54 \%$ \\
April 2017 & 179.157 & 139.395 & $22,19 \%$ \\
Mei 2017 & 209.084 & 160.752 & $23,12 \%$ \\
Juni 2017 & 164.793 & 176.456 & $7,08 \%$ \\
Juli 2017 & 159.797 & 184.345 & $15,36 \%$ \\
Agustus 2017 & 158.279 & 177.891 & $12,39 \%$ \\
September 2017 & 139.841 & 160.956 & $15,10 \%$ \\
Oktober 2017 & 137.103 & 152.639 & $11,33 \%$ \\
\hline
\end{tabular}

Sumber : Hasil Penelitian (2017)

Setelah hasil dari metode simple moving average diketahui maka diubah ke dalam bentuk grafik membandingkan penjualan aktual dengan ramalan menggunakan metode simple moving average.

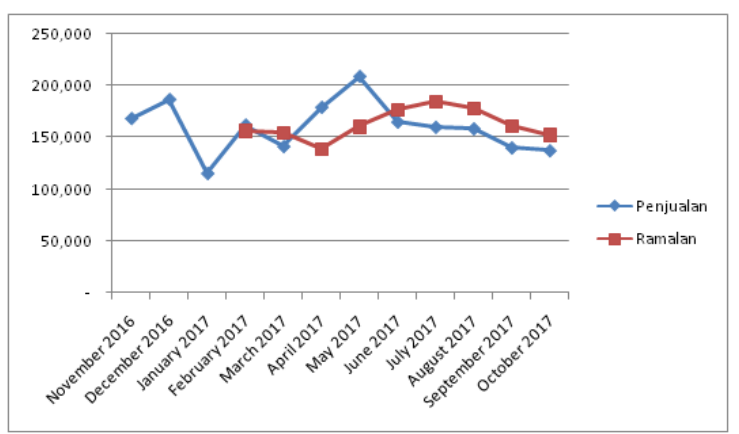

Gambar 2. Grafik Penj. Aktual dan Ramalan Metode Simple Moving Average Sumber : Hasil Penelitian (2017)

Dengan hasil diatas diperoleh kesimpulan metode simple moving average memiliki tingkat error hasil MAPE tertinggi dengan keakurasian sebesar $3.25 \%$ dan terendah dengan keakurasian sebesar 23.12\%.Dengan membandingkan metode Trend Moment dengan metode Simple Moving Average maka diketahuihasil MAPE tingkat keakurasian tertinggi 3.25\% dan terendahnya 23.12\% menggunakan metode Simple Moving Average. Sedangkan metodeTrend Moment memperoleh hasil MAPE tertinggi 4.08\% dan terendah 36.12\%. Oleh karena itu metode Simple Moving Average lebih unggul memprediksi penjualan ayam broiler pada CV. MerdekaAdi Perkasa. Kemudian data penjualan ayam broiler tersebut akan diolah untuk memprediksi beberapa bulan kedepan yang akan di urai perhitungan menggunakan metode Single Moving Average di bawah ini.

Untuk mencari data yang diujikan adalah data prediksi penjualan bulan November 2017 dengan amatan 3 bulan sebelumnya :

November $2017=\frac{158.279+139.841+137.103}{3}=$
145.074 (Forecasting)

Diketahui hasil dari peramalan sekitar 145.074 ayam broiler yang terjual pada bulan November 2017 jika ditarik peramalan yang terjadi saat bulan Oktober 2017 yaitu berkisar 152.639 ayam broiler yang akan terjual. Maka terjadi penurunan untuk penjualan berikutnya. Pada metode single moving average ini bergantung juga data penjualan aktual pada setiap bulannya agar dapat menentukan prediksi penjualan ayam broiler pada bulan yang akan datang. Jika menggunkan metode Trend Moment maka peramalan yang akan datang sebagai berikut :

$$
\begin{aligned}
& \text { (I) } 1.921 .262=12 \mathrm{a}+\mathrm{b}(66) \\
& \text { (II) } 10.380 .575=66 \mathrm{a}+\mathrm{b}(506) \quad \text { [x } 2] \\
& 21.133 .882=132 \mathrm{a}+726 \mathrm{~b}
\end{aligned}
$$




\section{$20.761 .150=132 \mathrm{a}+1.012 \mathrm{~b}$ \\ $372.732=-286 b$}

$$
\mathrm{b}=1.303
$$

Substitusikan

$$
\begin{aligned}
& \mathrm{b}=1.303 \\
& 12 \mathrm{a}=1.921 .262+85.998=2.007 .260 \\
& \mathrm{a}=2.007 .260 / 12 \\
& \mathrm{a}=167.272
\end{aligned}
$$

Maka, persamaan trend-nya

$\mathrm{a}+\mathrm{b}(\mathrm{x})$ :

$\mathrm{Y}=167.272+1.303(\mathrm{x})$

Dengan demikian, Forecast penjualan untuk kuartal ke $\mathrm{n}$ nilai x-nya mengikuti nilai $\mathrm{x}$ setelah bulan Oktober $\mathrm{x}$ $=11$ maka bulan selanjutnya dengan nilai $\mathrm{x}=12,13,14 \mathrm{dst}$.

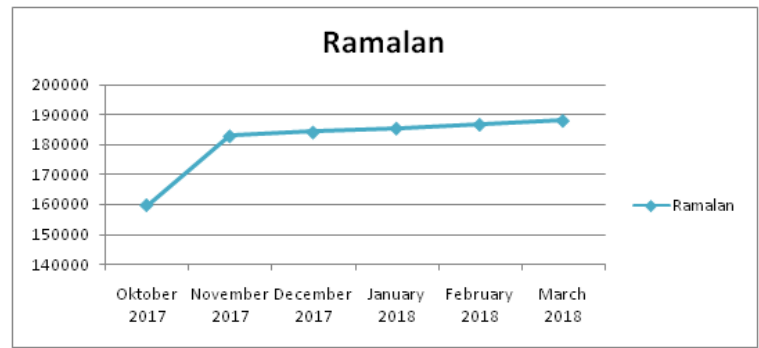

Gambar 3. Grafik RamalanPenjualan Ayam Broiler Sumber : Hasil Penelitian (2017)

\section{KESIMPULAN}

Berdasarkan uraian pembahasan pada bab-bab sebelumnya maka dapat diambil kesimpulan terhadap penelitian prediksi penjualan ayam broiler pada CV. Merdeka Adi Perkasa sebagai berikut :

1. Metode trend moment memperoleh hasil MAPE tertinggi $4.08 \%$ dan terendah $36.12 \%$ sedangkan metode simple moving average memperoleh hasil MAPE tertinggi $3.25 \%$ dan terendahnya $23.12 \%$.

2. Metode simple moving average lebih unggul memprediksi penjualan ayam broiler pada CV. Merdeka Adi Perkasa dibandingkan dengan metode trend moment.

\section{REFERENCES}

[1] Abdullah, Thamrin dan Francis Tantri. 2012. Manajemen Pemasaran. Depok : PT Raja Grafindo Persada.

[2] Arikunto, Suharsimi. 2010. Prosedur Penelitian Suatu Pendekatan Praktik. Jakarta : Rineka Cipta.

[3] Gusdian, Eby, Abdul Muis, Arifuddin Lamusa. 2016. "PERAMALAN PERMINTAAN PRODUK ROTI PADA INDUSTRI "TIARA RIZKI” DI KELURAHAN BOYAOGE KECAMATAN TATANGA KOTA PALU”. e-Journal Agrotekbis 4 (1):97-105.

[4] Heizer, J. \& Render, B. 2011. Operations Management. Tenth Edition. Pearson, New Jersey, USA.

[5] Nurlifa, Alfian dan Sri Kusumadewi. 2017. "Sistem Peramalan Jumlah Penjualan Menggunakan Metode Moving Average Pada Rumah Jilbab Zaky”. JURNAL INOVTEK POLBENG - SERI INFORMATIKA, VOL. 2, NO. 1.

[6] Ratningsih. 2017. "Forecasting Penjualan Rumah Dengan Menggunakan Metode Trend Moment Pada PT.Rumakita Prima Karsa". Jurnal Perspektif, Vol. XV, No. 1.

[7] Riduwan. 2010. Metode dan Teknik Menyusun Tesis. Bandung : Alfabeta.

[8] Satzinger, Jackson, Burd. 2010. "System Analisis and Design Process". USA : Course Technology, Cengage Learning.

[9] Sugiyono. 2010. Metode Penelitian Kuantitatif Kualitatif dan R\&D. Bandung. Alfabeta.

[10] Turban, E, et al. 2007. Decision Support and Business Intelligence Systems ( $7^{\text {th }}$ Edition). New Delhi : Pearson Prentice Hall.

[11] J. Simarmata, Rekayasan Perangkat Lunak. Bandung: Andi Offset, 2015.

[12] H. Utari, M. Mesran, and N. Silalahi, "Perancangan Aplikasi Peramalan Permintaan Kebutuhan Tenaga Kerja Pada Perusahaan Outsourcing Menggunakan Algoritma Simple Moving Average," J. Times (Technology Informatics Comput. Syst., vol. 5, no. 2, pp. 1$5,2016$.

[13] S. Barus, V. M. Sitorus, D. Napitupulu, M. Mesran, and S. Supiyandi, "Sistem Pendukung Keputusan Pengangkatan Guru Tetap Menerapkan Metode Weight Aggregated Sum Product Assesment ( WASPAS )," MEDIA Inform. BUDIDARMA, vol. 2, no. 2, pp. 10$15,2018$. 